\title{
PEMURNIAN ETANOL HASIL FERMENTASI \\ KULIT UMBI SINGKONG (Manihot Utilissima Pohl) \\ DARI LIMBAH INDUSTRI KERUPUK SANJAI \\ DI KOTA BUKITTINGGI \\ BERDASARKAN SUHU DAN WAKTU DESTILASI
}

\section{ETHANOL PURIFICATION PRODUCED BY FERMENTED CASSAVA'S (Manihot Utilissima Pohl) PEEL FROM INDUSTRIAL WASTE OF CRACKERS SANJAI IN BUKITTINGGI BASED ON TEMPERATURE AND DISTILLATION TIME}

\author{
Mhd. Riza Marjoni \\ Akademi Farmasi Dwi Farma Bukittinggi \\ JL Prof DR. Hamka, Lambau, Indonesia \\ Email:mhdriza.marjoni@gmail.com
}

\begin{abstract}
ABSTRAK
Kota Bukittinggi dengan lebih kurang 132 industri kerupuk sanjai menghabiskan 300$500 \mathrm{Kg}$ singkong perhari untuk setiap industri. Limbah padat hasil proses produksi kerupuk sanjai ini salah satunya adalah kulit singkong. Singkong yang dikupas menghasilkan 15-20\% kulit dengan kandungan karbohidrat 68-85\% dari berat keseluruhan umbi, sehingga memiliki potensi besar untuk dikonversi menjadi bioetanol. Karbohidrat pada kulit umbi dapat diolah menjadi bioetanol secara fermentasi dan untuk memisahkan bioetanol dari campuranya digunakan metoda destilasi.Suhu dan waktu destilasi yang digunakan mempengaruhi kualitas dan kuantitas bioetanol yang dihasilkan. Penelitian ini bertujuan untuk mengetahui suhu dan waktu destilasi terbaik dalam menghasilkan bioetanol dengan kadar tertinggi. Analisis kadar etanol dilakukan dengan metode bobot jenis menggunakan persamaan regresi linear dan Tabel bobot jenis Farmakope Indonesia. Hasil penelitian menunjukan bahwa kadar etanol destilat tertinggi diperoleh pada suhu destilasi $71^{\circ} \mathrm{C}$ selama 5 jam yaitu $16,60 \%$ menggunakan metode regresi dan 14,1\% menurut Tabel Farmakope dengan Rendemen berkisar antara 2,30\% - 5,80\% dan efisiensi destilasi 28,94\% - 57,50\%. Waktu dan suhu destilasi memiliki pengaruh yang nyata terhadap kadar bioetanol yang dihasilkan pada taraf 5\%
\end{abstract}

Kata kunci: Manihot uttilissima, destilasi, suhu destilasi, waktu destilasi, etanol,

\begin{abstract}
Bukittinggi city with approximately 132 industry crackers Sanjai spend 300-500 kg of cassava per day for each industry. Solid waste production process results Sanjai crackers this one is skin cassava. Cassava's peel produces $15-20 \%$ carbohydrate content of $68-85 \%$ of the weight of the bulb, so it has great potential to be converted into bioethanol. Carbohydrates in the tuber peel can be processed into ethanol by fermentation and for separating ethanol from it's mixture used method of distillation. Distillation temperature and time used
\end{abstract}


affects the quality and quantity of bioethanol produced. This study aims to determine the best time and temperature distillation to produce bioethanol at the highest levels. Ethanol content analysis was conducted using the specific gravity using line arregression equation and Table gravity of Indonesian Pharmacopoeia. The results showed that the highest levels of ethanol distillate obtained in the distillation temperature of $71^{\circ} \mathrm{C}$ for 5 hours is $16.60 \%$ using regression methods and $14.1 \%$ according to Table Pharmacopoeia with yield ranging between $2.30 \%$ $5.80 \%$ and the efficiency of distillation $28,94 \%-57.50 \%$. Time and temperature distillation have a real impact on the levels of ethanol produced atthe level of $5 \%$

Keywords: Manihotuttilissima, distillation, distillationtemperature, time of distillation, ethanol

\section{PENDAHULUAN}

Kota Bukittinggi terkenal dengan pengahasil penganan yang dibuat dari ubi kayu yang terkenal dengan nama"Karupuak Sanjai”. Di Kota Bukittinggi terdapat 132 pengusaha industri kerupuk sanjai yang mampu menghabiskan 300-500 Kg singkong perhari untuk setiap industri (Anonim, 2013).

Salah satu limbahyang dihasilkan dari proses produksi sanjai tersebut adalah kulit umbi singkong. Penelitian Sriroth (2008) melaporkan bahwa 10 milliar ton umbi singkong dapat menghasilkan kulit umbi singkong sebanyak 0,3 milliar ton dan baru 0,1 milliar ton yang digunakan untuk pakan ternak, pupuk, dan media pertumbuhan jamur (Sriroth, 2008).

Beberapa fakta penting lainya menunjukan bahwa setiap singkong yang dikupas dapat menghasilkan 15-20\% kulit umbi dengan kandungan karbohidrat berkisar antara 68-85\% dari berat keseluruhan kulit umbi singkong. Data ini menunjukkan bahwa kulit umbi singkong memiliki potensi yang cukup besar untuk digunakan dalam menghasilkan suatu produk yang bermanfaat seperti etanol atau lazim disebut dengan bioetanol (Cuzin et al., 1991).

Bietanol yang diperoleh pada akhir proses fermentasi masih berupa campuran antara air dengan etanol. Campuran larutan tersebut dapat dipisahkan dengan cara destilasi, karena destilasi mampu memisahkan dua atau lebih komponen cairan berdasarkan perbedaan titik dididhnya.Tujuan dari proses destilasi ini adalah untuk memurnikan zat cair pada titik didihnya serta memisahkan cairan dari campurannya yang mempunyai titik didih yang berbeda. Perbedaan titik didih antara air dan etanol yang cukup besar memungkinkan terjadinya pemisahan campuran etanol dan air.(Soerawidjaja, 2007).

Proses pemisahan campuran etanol dan air dengan cara destilasi sangat dipengaruhi oleh banyak faktor diantaranya adalah faktor suhu saat destilasi dan lamanya waktu destilasi. Kedua faktor ini sangat mempengaruhi kemurnian etanol yang dihasilkan, efisiensi etanol yang diperoleh, rendemen serta kadar etanol. Suhu destilasi dan lamanya proses destilasi juga akan memiliki efek terhadap kualitas dan kuantitas etanol yang dihasilkan.

Berdasarkan uraian tersebut diatas, perlu dilakukan suatu penelitian untuk mengetahui kualitas dan kuantitatif etanol hasil fermentasi kulit umbi singkong yang bersumber dari limbah industri kerupuk sanjai di Kota Bukittinggi berdasarkan suhu dan lamanya waktu destilasi.

\section{METODE PENELITIAN}

\section{Alat}

Alat yang digunakan dalam penelitian ini meliputi timbangan digital, gelas ukur, erlenmenyer, pipet volume, timer, termometer, $\mathrm{pH}$ meter (Hanna), fermentor, 
aluminium foil, alat destilasi sederhana, labu ukur, Piknometer.

\section{Bahan}

Bahan yang digunakan adalah kulit ubi kayu (Manihot utilissima Pohl) limbah industri kerupuk sanjai di daerah Sanjai Kota Bukittinggi Sumatera Barat.

Bahan pembantu yang digunakan dalam penelitian ini adalah ragi roti dengan merk dagang fermipan ${ }^{\circledR}, \mathrm{NaOH}, \mathrm{HCl}$, dan aquades, etanol p.a (E. Merck), alumunium foil. Aspergillus niger

\section{Jalannya Penelitian}

\section{Persiapan Bahan}

Satu kilogram limbah kulit umbi singkong dicuci bersih dan dibiarkan mengering. Kulit umbi dihaluskan dengan blender kemudian disaring sehingga diperoleh pati limbah kulit singkong. Pati limbah ditambah dengan air dan dipanaskan sambil diaduk sampai mendidih. Pedidihan dipertahankan selama 15 menit sambil terus diaduk. Bahan kemudian didinginkan lebih kurang 1 jam, lalu dimasukkan ke dalam tempat sakarifikasi.

\section{Sakarifikasi}

Bahan dalam media sakarifikasi ditambahkan Aspergillus niger 10\% dari total larutan. Dibiarkan lebih kurang 2 jam agar Aspergillus niger berkembang biak dan bekerja mengurai pati. Setelah 2 jam bubur akan berubah menjadi 2 lapisan yaitu lapisan air dan endapan gula.

\section{Fermentasi kulit Umbi singkong}

Pati yang sudah menjadi gula diaduk dan diatur $\mathrm{pH}$ antara 4,5-5,5 dengan penambahan $\mathrm{HCl} \quad 0,1 \mathrm{~N}$ atau $\mathrm{NaOH} 0,1 \mathrm{~N}$. Ditambahkan ragi roti merek fermipan $0,5 \%$ (b/v). Fermentasi dilakukan selama 3 hari secara anaerob pada suhu pada $28-32^{0} \mathrm{C}$.

\section{Pemurnian etanol}

Bioetanol hasil fermentasi disaring untuk memisahkan larutan fermentasi dengan kotoran yang tercampur didalam larutan. Filtrat kemudian di destilasi untuk memisahkan etanol dari larutan fermentasi yang terbentuk sesuai dengan rancangan percobaan yang telah ditentukan. Destilat disimpan dalam botol untuk analisis

\section{Pengujian Etanol destilat berdasar- kan regresi dan Farmakope Indo- nesia}

\section{a. Pembuatan Larutan Standar Etanol $12 \%$}

Etanol p.a diambil sebanyak $30 \mathrm{~mL}$ dengan menggunakan pipet volumetri dan dimasukkan kedalam labu takar 250 mL,ditambahkan akuades hingga garis tanda kemudian dihomogenkan. Replikasi dilakukan sebanyak 3 kali.

\section{b. Pembuatan seri larutan baku etanol}

Disiapkan seri baku dengan konsentrasi 5,10,15,20 dan 25\% dengan penambahan etanol p.a masing-masing 5, 10, 15, 20 dan 25 $\mathrm{ml}$ dan dicukupkan masing-masing dengan aquadest sampai $100 \mathrm{ml}$.

\section{c. Penentuan bobot jenis relative}

Piknometer diisi dengan aquadest dan dibersihkan dengan tissue, kemudian ditimbang dan diisi dengan larutan standar referensi. Piknometer dibersihkan dengan tissue, ditimbang. Bobot jenis Relatif dihitung dengan Rumus :

\section{$\mathrm{BJR}=\underline{\text { Berat Larutan Baku EtOH }} \times 100 \%$}

\section{Berat Air}

\section{d. Penentuan kadar etanol}

Bobot jenis etanol yang diperoleh dengan metode piknometer, kemudian plot terhadap persamaan regresi linear kurva standar. 
Dilakukan hal yang sama dengan melihat Tabel Kadar Etanol yang terdapat pada Farmakope Indonesia.

\section{e. Pengamatan dan Analisa Data}

Pengamatan dan analisa yang dilakukan dalam penelitian ini meliputi:

1) Rendemen, dapat dihitung dengan rumus:

$\frac{\text { Volume destilat etanol }(\mathrm{ml})}{\text { Volume larutan fermentasi awal }(\mathrm{ml})} \times 100 \%$

2) Efisiensi destilasi, dapat dihitung dengan rumus:

$\frac{\text { Volume destilat }(\mathrm{ml})}{\text { Volume larutan terdestilasi }(\mathrm{ml})} \times 100 \%$

3) Recovery di hitung dengan rumus:

4) Kesalahan Sistemik

$$
\frac{\text { Kadar terukur }}{\text { Kadar sebenarnya }} \times 100 \%
$$

5) Kesalahan acak

$$
\text { 100\% - Recovery }
$$

$$
\frac{\text { Standar Deviasi }}{\text { rata-rata kadar terukur }} \times 100 \%
$$

\section{HASIL DAN PEMBAHASAN}

Rata - rata nilai rerata rendemen yang diperoleh pada penelitian ini berkisar antara $2,30 \% \quad-5,80 \%$ dengan nilai tertinggi rendemen adalah $5,80 \%$ pada suhu $85^{\circ} \mathrm{C}$ selama 5 jam. Hasil analisis ragammenunjukkan bahwa kombinasi perlakuan antara suhu dan waktu destilasi memiliki pengaruh yang nyata terhadap rendemen yang dihasilkan pada $\alpha=0,05$.

Dari data pada Tabel I dapat diketahui bahwa tidak terlihat pengaruh yang nyata terhadap rendemen pada proses destilasi selama 3 dan 4 jam dengan suhu $71^{\circ} \mathrm{C}$. Rendemen baru menunjukan pengaruh yang nyata pada waktu destilasi dinaikan menjadi 5 jam, dengan nilai rendemen yang diperoleh sebesar 2,87\%.

Peningkatan suhu destilasi dari $71{ }^{\circ} \mathrm{C}$ menjadi $78{ }^{0} \mathrm{C}$ pada waktu destilasi 3 jam tidak mempengaruhi nilai rendemen. Nilai Rendemen baru berpengaruh pada waktu destilasi 4 jam dan 5 jam. Pengaruh yang sangat berarti terjadi pada saat destilasi dengan suhu $85^{\circ} \mathrm{C}$ selama 3 sampai 5 jam.

Tabel I. Hasil Analisa Rendemen (\%)

\begin{tabular}{lcccc}
\hline \multirow{2}{*}{ Perlakuan } & \multicolumn{3}{c}{ Ulangan } & \multirow{2}{*}{ Rata-Rata } \\
\cline { 2 - 4 } & I & II & III & \\
\hline S1T1 & 2,3 & 2,3 & 2 & 2,3 \\
S1T2 & 2,4 & 2,4 & 2 & 2,41 \\
S1T3 & 3 & 2,8 & 3 & 2,87 \\
S2T1 & 2,9 & 2,8 & 3 & 2,88 \\
S2T2 & 3,4 & 3,4 & 3 & 3,33 \\
S2T3 & 3,4 & 3,6 & 4 & 3,53 \\
S3T1 & 3,9 & 3,8 & 4 & 3,83 \\
S3T2 & 5,2 & 5,2 & 5 & 5,07 \\
S3T3 & 5,8 & 5,6 & 6 & 5,8 \\
\hline
\end{tabular}

Peningkatan rendemen mulai suhu $71^{\circ} \mathrm{C}$ seiring dengan semakin meningkatnya waktu destilasi. Destilasi selama 3 jam pada suhu $71^{\circ} \mathrm{C}$ menghasilkan rendemen sebesar $2.3 \%$, kemudian meningkat menjadi $2.41 \%$ dengan waktu 4 jam dan terus meningkat menjadi $2.87 \%$ dengan waktu destilasi selama 5 jam.

Peningkatan suhu menjadi $78^{\circ} \mathrm{C}$ dan waktu destilasi juga diiringi dengan peningkatan rendemen. Destilasi selama 3 jam pada suhu ini menghasilkanrendemen sebesar 2,88\%. Kemudian nilai rendemen meningkat menjadi 3,33\% padawaktu destilasi 4 jam, dan terus meningkat pada waktu destilasi selama 5 jam menjadi 3,53\%.

Semua tingkatan waktu destilasi dan suhu destilasi juga ikut meningkatkan rendemen yang dihasilkan. Destilasi selama 3 jam pada suhu ini menghasilkan rendemen sebesar 3,83\%. Kemudianmeningkat menjadi 5,07\% pada waktu 4 jam dan terus meningkat menjadi 5,8\%dengan waktu destilasi selama 5 jam. 


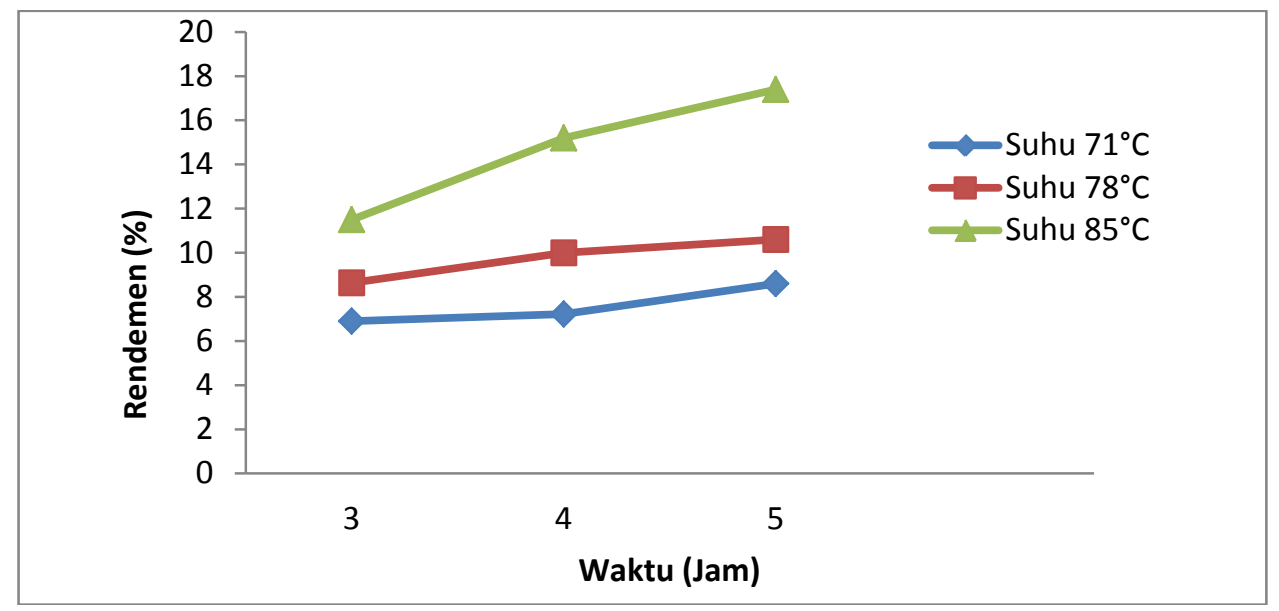

Gambar 1.Grafik Pengaruh suhu dan waktu destilasi terhadap rata-rata rendemen

Nilai rendemen terus meningkat seiringdengan peningkatan suhu dan waktu destilasi.Peningkatan nilai rendemen ini disebabkan karena peningkatan suhu dan waktu destilasi menyebabkan cairan yang dapat diuapkan.Uap yang dihasilkan terkondensasi menjadi etanol destilat pada labu penampung destilat.

Selain pengaruh suhu dan waktu destilasi, nilai rendemen juga sangat dipengaruhi oleh bahan baku, proses, dan alat destilasi yang digunakan. Pada penelitian ini digunakan alat destilasi yang sangat sederhana, sehingga nilai rendemen yang dihasilkan tidak terlalu besar. Upaya untuk meningkatkan nilai rendemen yang dihasilkan dapat dilakukan dengan menambah lama waktu destilasi sehingga larutan fermentasi yang teruapkan akan semakin bertambah.

Rendemen yang diperoleh pada penelitian ini sangat jauh lebih kecil bila dibandingkan dengan rendemen dari umbi kayu itu sendiri. Berdasarkan Penelitian yang dilakukan oleh Duryatmo (2008) mengemukakan bahwa dalam 6,5 kg ubi kayu dapat menghasilkan 1 liter etanol dengan nilai rendemen 15,38\%. Begitu juga penelitian yang dilakukan oleh Suryanto (1999) terhadap kinerja alat penyulingan fraksinasi, menunjukkan bahwa dengan perlakuan selama 3 jam dihasilkan rata- rata rendemen 19\%.
Hasil analisa ragam menunjukkan bahwa faktor suhudestilasi dan waktu destilasi serta interaksi antara kedua faktor tersebutmemiliki pengaruh yang nyata terhadap efisiensi destilasi pada taraf $\alpha=$ 0,05. Nilai rerata efisiensi destilasi pada pemurnian etanol dari fermentasi kulit umbi kayu berkisarantara 28,94\% - 57,50\%.

Tabel II. Hasil analisa efisiensi destilasi (\%)

\begin{tabular}{lcccc}
\hline \multirow{2}{*}{ Perlakuan } & \multicolumn{3}{c}{ Ulangan } & Rata-Rata \\
\cline { 2 - 4 } & I & II & III & \\
\hline S1T1 & 57,5 & 57,5 & 57,5 & 57,5 \\
S1T2 & 43,21 & 40 & 40 & 41,07 \\
S1T3 & 50 & 46,7 & 46,7 & 47,8 \\
S2T1 & 36,25 & 35,5 & 37,17 & 36,31 \\
S2T2 & 34 & 34 & 32 & 33,33 \\
S2T3 & 30,9 & 33,33 & 32,72 & 32,32 \\
S3T1 & 32,5 & 31,67 & 31,67 & 31,95 \\
S3T2 & 32,5 & 34,67 & 30,76 & 32,64 \\
S3T3 & 34,11 & 25,45 & 27,27 & 28,94 \\
\hline Total & 350,97 & 338,82 & 335,79 & 341,86 \\
\hline
\end{tabular}

Destilasi pada suhu $71^{\circ} \mathrm{C}$ tidak meiliki pengaruh yang nyata terhadap efisiensi destilasi untuk semua variasi waktu. Pengaruh baru terlihat pada saat suhu destilasi dinaikan menjadi $78^{\circ} \mathrm{C}$ pada waktu 3 jam dan 4 jam. Nilai efisiensi destilasi tertinggi diperoleh 
pada suhu $71^{\circ} \mathrm{C}$.Waktu destilasi sampai pada suhu $85^{\circ} \mathrm{C}$ tidak memmpengaruhi nilai efisiensi destilasi yang diperoleh.Peristiwa ini menunjukan bahwa, pada suhu $85^{\circ} \mathrm{C}$ telah terjadi keseimbangan jumlah bahan teruapkan dan seluruh fase cair dalam larutan telah teruapkan seluruhnya sehingga tidak ada lagi penguapan larutan pada suhu tersebut.

Rata - rata efisiensi destilat tertinggi terdapat pada suhu destilasi $71^{\circ} \mathrm{C}$ dengan lama destilasi 1 jam yaitu 57,50\%, sedangkan rerata efisiensi destilasi terendah diperoleh padaperlakuan dengan suhu destilasi $85^{\circ} \mathrm{C}$ dan waktu destilasi selama 5 jam dengannilai sebesar 28,94\%. Perolehan nilai efisiensi tertinggi diperoleh pada suhu $71^{\circ} \mathrm{C}$,karena etanol menguap pada suhu 70 derjat dan peningkatan suhu yang melebihititik didih alkohol selama proses penyulingan, menyebabkan molekul-molekul air dansenyawa-senyawa organik ikut menguap bersama-sama dengan alkohol (Suryanto,1999).

Tabel III. Hasil analisa kadar etanol destilat (\%)

\begin{tabular}{lcccc}
\hline \multirow{2}{*}{ Perlakuan } & \multicolumn{3}{c}{ Ulangan } & \multirow{2}{*}{ Rata-Rata } \\
\cline { 2 - 4 } & I & II & III & \\
\hline S1T1 & 38,38 & 38,39 & 38,39 & 38,39 \\
S1T2 & 42,41 & 41,61 & 40 & 41,34 \\
S1T3 & 62,58 & 63,38 & 62,58 & 62,85 \\
S2T1 & 61,77 & 61,77 & 61,77 & 61,77 \\
S2T2 & 56,93 & 56,12 & 56,93 & 56,66 \\
S2T3 & 29,51 & 30,32 & 31,12 & 30,32 \\
S3T1 & 46,45 & 44,83 & 46,45 & 45,91 \\
S3T2 & 23,06 & 21,45 & 23,06 & 22,52 \\
S3T3 & 17,41 & 17,41 & 15,8 & 16,87 \\
\hline
\end{tabular}

Pada Penelitian ini diperoleh kadar etanol berkisar antara 1,02-16,60\% berdasarkan metoda regresi dan 1,6-14,1\% menurut Tabel Etanol Farmakope Indonesia Edisi III Tahun 1979. Rata-rata etanolyang dihasilkan adalah 6,64\% menurut metode regresi dan 5,75\% menurut Metode
Farmakope Indonesia dengan kadar tertinggi dihasilkan pada perlakuan dengan suhu destilasi $71^{\circ} \mathrm{C}$ selama 5 jam. Hasil analisis ragam menunjukkan bahwa kombinasi perlakuan antara suhu dan waktu destilasi mempunyai pengaruh terhadap kadar etanol destilat yang dihasilkan baik dengan metode regresi maupun dengan metoda Farmakope Indonesia.

\section{Tabel IV. Perbandingan kadar etanol destilat metode regresi dan metode Farmakope}

\begin{tabular}{ccc}
\hline Perlakuan & $\begin{array}{c}\text { Metode } \\
\text { Regresi }\end{array}$ & $\begin{array}{c}\text { Metode } \\
\text { Farmakope }\end{array}$ \\
\hline S1T1 & 3,23 & 3,2 \\
S1T2 & 5,4 & 5 \\
S1T3 & 16,6 & 14,1 \\
S2T1 & 11,5 & 9,7 \\
S2T2 & 9,62 & 7,7 \\
S2T3 & 2,7 & 2,7 \\
S3T1 & 7,47 & 5,7 \\
S3T2 & 2,29 & 2,1 \\
S3T3 & 1,02 & 1,6 \\
\hline
\end{tabular}

Destilasi pada suhu $78^{0} \mathrm{C}$ dan suhu $85^{\circ} \mathrm{C}$ tidak mempunyai pengaruh yang nyata terhadap kadar etanol destilat yang dihasilkan. Hal ini disebabkan karena sudah terdapat keseimbangan antara jumlah etanol dan uap air yang terdestilasi.

Sedangkan pada suhu $71^{\circ} \mathrm{C}$, dengan waktu destilasi selama 4 dan 5 jam mempunyai pengaruh nyata terhadap kadar etanol destilat. Hal ini disebabkan karena titik didih etanol yang berada pada suhu antara $70^{\circ} \mathrm{C}-78^{\circ} \mathrm{C}$. Pada suhu $78^{\circ} \mathrm{C}$ etanol telah lebih dulu menguap dari air.Etanol yang menguap pada suhu ini lebih banyak dari fase cair lain yang terlarut di dalam larutan fermentasi yang sedang didestilasi.

Kadar etanol destilat yang diperoleh pada penelitian ini sangat bervariasi sesuai dengan peningkatan suhu dan waktu destilasi. 


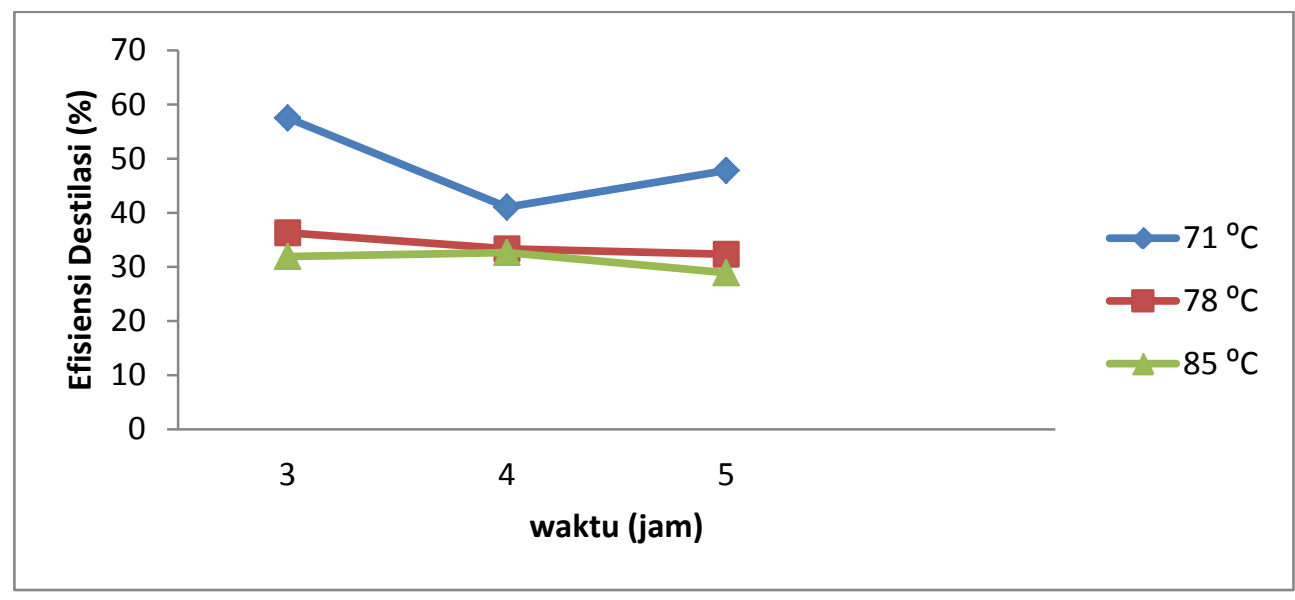

\section{Gambar 2. Grafik pengaruh suhu dan waktu destilasi terhadap efisiensi destilasi}

Peningkatan waktu destilasi pada suhu $71^{0} \mathrm{C}$ ikut meningkatkan kadar etanol destilat. Sedangkan peningkatan suhu destilasi cendrung menurunkan kadar etanol destilat. Hal ini disebabkan oleh bertambahnya jumlah air yang ikut menguap dengan jumlah tidak sebanding lagi dengan jumlah etanol yang diuapkan.

Peningkatan suhu menjadi $85^{\circ} \mathrm{C}$ membuat kadar etanol destilat yang dihasilkan semakin menurun seiring dengan bertambahnya waktu destilasi, karena semakin banyak fase cair lain selain etanol yang ikut teruapkan pada saat proses destilasi berlangsung.

Kadar etanol destilat yang diperoleh dalam penelitian ini masih sangat rendah jika akan digunakan sebagai bahan baku pembuat bahan bakar, karena pada penelitian ini, kadar etanol yang diperoleh hanya mencapai $16,60 \%$ menurut perhitungan regresi dan $14,1 \%$ berdasarkan metode Farmakope Indonesia. Sementara itu, agar bisa digunakan sebagai bahan bakar, diperlukan etanol dengan kadar 99,5\% atau bahkan lebih.

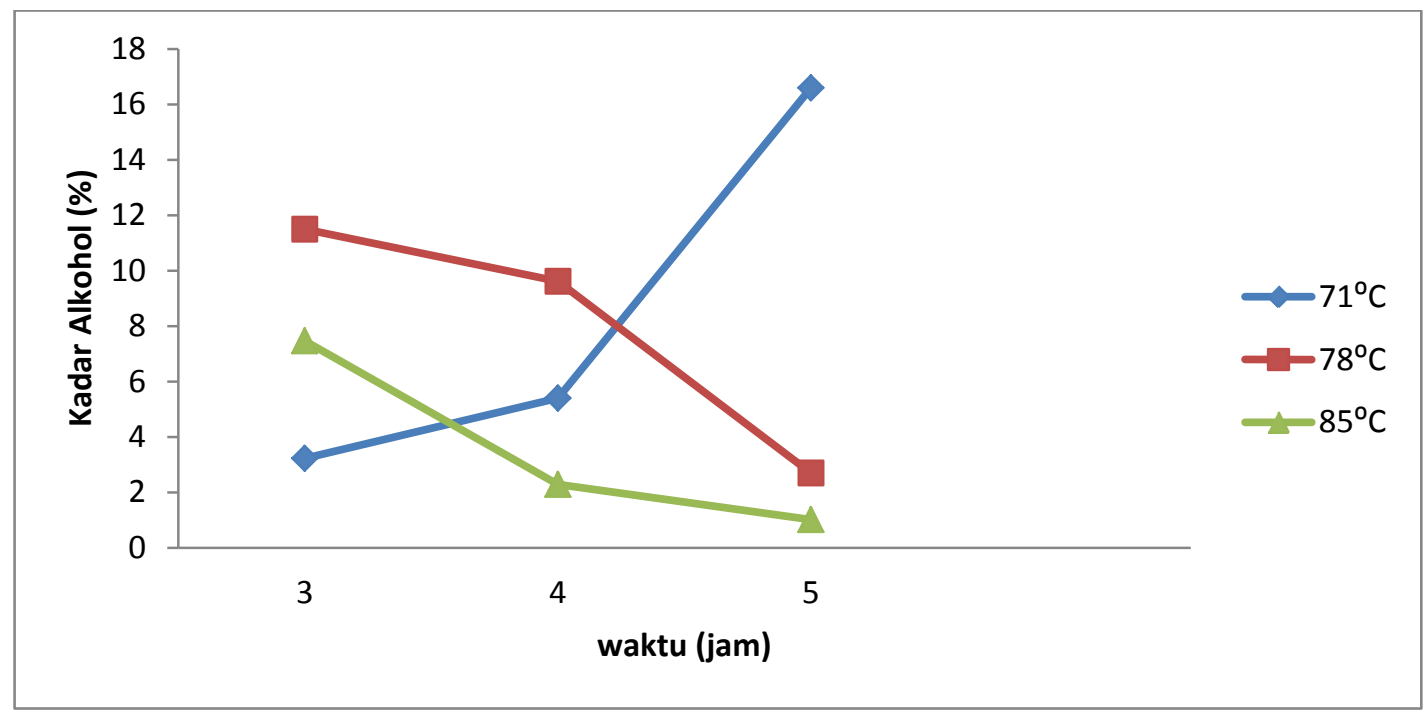

Gambar 3.Grafik pengaruh suhu dan waktu destilasi terhadap kadar etanol 
Pemilihan rendemen, efisiensi destilasi dan kadar etanol terbaik adalah dengan cara memilih kombinasi perlakuan yang menghasilkan nilai rendemen, efisiensi destilasi dan kadar etanol destilat tertinggi. Pada penelitian ini dihasilkan rendemen tertinggi pada suhu $85^{\circ} \mathrm{C}$ dengan waktu pendestilasian selama 5 jam yaitu 5,80\%. Efisiensi tertinggi diperoleh pada waktu destilasi 3 jam dengan suhu destilasi $71{ }^{\circ} \mathrm{C}$ yaitu 57,50\%. Sedangkan kadar etanol destilat tertinggi diperoleh saat destilasi pada suhu $71^{\circ} \mathrm{C}$ selama 5 jam dengan kadar 16,60\% dengan metode Regresi dan 14,1\% dengan Metode Farmakope Indonesia. Kadar alkohol yang diperoleh pada penelitian ini sangat bervariasi seiring dengan pertambahan waktu dan suhu destilasi.

\section{KESIMPULAN}

Pada penelitian pemurnian etanol dari fermentasi kulit ubi kayu limbah industri kerupuk sanjai di Kota Bukittinggi dapat disimpulkan bahwa kadar etanol destilat tertinggi, yaitu sebesar $16,60 \%$ menurut metode Regresi dan 14,1\% menurut Metode Farmakope Indonesia dengan suhu destilasi $71^{\circ} \mathrm{C}$ selama selama 5 jam. Waktu dan suhu destilasi memiliki pengaruh yang nyata terhadap kadar bioetanol yang dihasilkan

\section{DAFTAR PUSTAKA}

Anonim. 1995. Farmakope Indonesia Edisi IV. Depkes RI. Jakarta
Anonim. 2013. Bukittingi Kota Sanjai http://www.kumpulanpangai.blo gspot.com/2010/11/Bukittinggi-Kotawisata.html, Tanggal akses Desember 2013

Cuzin, N.,Farinet, J.L.\& Segretain, C. 1991. Anaerobic fermentation of solid cassava wastes in continuous pilot scale fermenter. In: Grassi G, Delmon B, Molle JF, Zibetta H (eds) Biomass for Energy and Industry 4th E.C. Conference Elsevier Applied Science, London, pp. 2383-2387.

Grace, M. R. 1977. Cassava Processing: Food and Agriculture Organization. Henniiee.

\section{Roma}

Soerawidjaja, T. H. 2007. Mengebor Bensin di

Kebun Singkong. http://www.indobiofuel.com/ cara\%20membuat\%20bioethanol\%20si ngkon g.php.Tanggal akses 23 Januari 2014

Sriroth, K., Piyachomkwan, K, and Y. Tokiwa. 2008. Application of bipolar electrodialysis on recovery of free lactic acid after simultaneous saccharification and fermentation of cassava starch. Biotechnology Letter. 30: 1747-1752. 